\title{
PERSPECTIVE
}

\section{Smoking Ban - Made in Ireland, for Home Use and for Export}

N. Gerry McElvaney, M.D.

On March 29, 2004, the Irish government implemented a law banning smoking in the workplace. This was the first law of its kind in Europe and represented the culmination of many decades of antismoking legislation and campaigning.

As early as the 16th century, people in Ireland recognized the problems with tobacco consumption. One of the earliest references to these problems was by the priest and poet Brian Mac Giolla Phadraig, who, lamenting the decline of his native country, attributed it at least in part to "a stoc tobac 'na clab da lantseideadh" (tobacco pipe in jaw, at full blow). Despite this recognition, tobacco consumption increased in Ireland and was widespread among all classes of society. Insidiously, it became associated with alcohol consumption, and a common practice in Ireland from the 17th century to the 20th was to give out small pipes of tobacco (duidins) along with copious alcohol at wakes and weddings.

In the 1830s, the great temperance crusader Father Matthew railed against the evils of alcohol but did not attach the same importance to tobacco smoke, believing it to be a lesser evil. The use of cigarettes spread in Ireland, particularly after the First World War, and for some time, the harm caused by cigarette smoking fell below the radar of most health care professionals and the general public. Although articles addressing the health effects of smoking began to appear in medical journals by the early 20th century, it was not until 1952 that this issue was brought to the attention of the general public. In that year, Reader's Digest published an article entitled "Cancer by the Carton," outlining for the first time to a lay audience the health implications of tobacco use.

As early as 1964, the Department of Health and Children in Ireland adopted an integrated approach to the control of tobacco consumption, involving both statutory and voluntary controls on industry's behavior with respect to the environment, as well as health education. This approach evolved, leading to a series of laws prohibiting the advertising of to- bacco products in the electronic media and placing restrictions on access to advertising in the print media. In addition, the level of spending on advertising and sponsorship by tobacco companies was controlled by law. Ireland also imposed a policy that kept prices on tobacco products high through a system of retail-price management and taxation; the country had one of the highest tobacco taxes in the European Union, and retailers were permitted to sell cigarettes for no less than 97 percent of the price set by the government. Multimedia educational campaigns were also introduced. A voluntary prohibition on smoking in the workplace was developed by the Health Promotion Unit of the Department of Health and Children with the support of the Irish Congress of Trade Unions, the Irish Business and Employers Confederation, the Irish Cancer Society, the Irish Heart Foundation, and the Health and Safety Authority. This code established, in the area of tobacco control, the consultative approach between industry and the trade unions that had proved so successful in economic development and that would be pivotal to the success of any legislation in the area of tobacco control.

The result of these measures was a reduction in the prevalence of smoking from 45 percent in the mid-1970s to about 28 percent in the early 1990s. However, there was still evidence of a major tobaccorelated health crisis in Ireland. In 1994, Ireland ranked 12th among the 15 countries in the European Union with regard to life expectancy for women and 9th with regard to life expectancy for men. Heart disease and cancer were the principal causes of premature death, with coronary artery disease accounting for 1 in 4 deaths at all ages and stroke accounting for 1 in 10 deaths. Mortality from cancer in Ireland, particularly lung cancer, remained significantly above the average for the European Union. In 1989, the proportion of deaths in Ireland that were attributable to smoking was 21.2 percent. These data did not take into account the enormous morbidity also associated with cigarette smoking. 


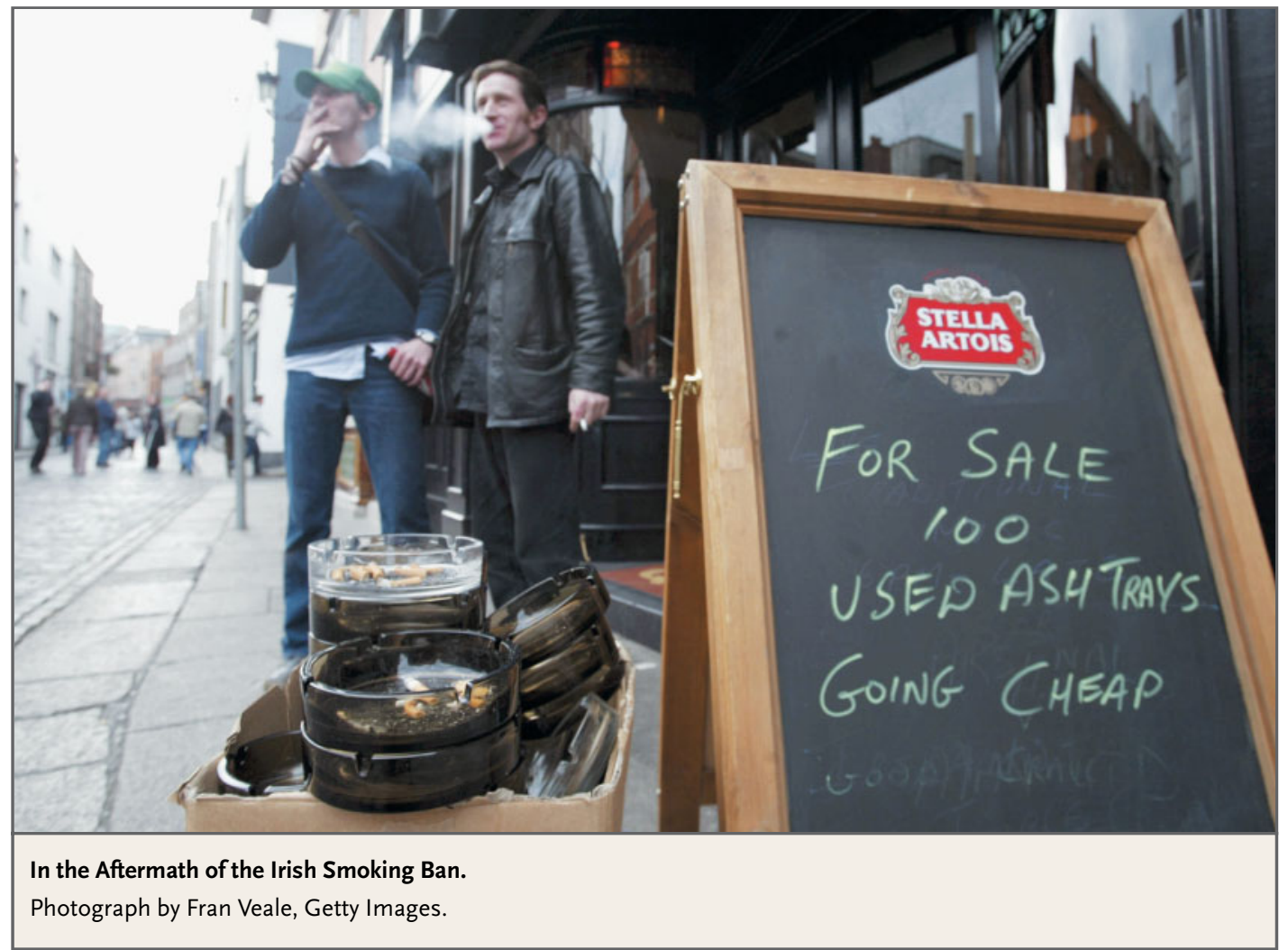

There were a number of weaknesses in the programs aimed at tobacco control. Public awareness of the problems and agreement about the need for tobacco control were perceived to be vital not only for better health among the population, but also for the support required to pass effective legislation. In 1999, the Oireachtas (Parliament) Joint Committee on Health and Children, composed of politicians from across the political spectrum, examined the issue of smoking and health. They sought the views of a wide range of groups, including representatives of the tobacco industry. The committee unanimously recommended a revised antismoking strategy. One of the most important outcomes of this process was the establishment of the Office of Tobacco Control. In 2001, a tobacco bill was introduced that gave the minister for health and children the power to create smoke-free working environments. This bill was signed into law in 2002, but there was still disagreement about how widely these restrictions should be applied. The same year, the Office of Tobacco Control, together with the Health and Safety Authority, commissioned a pivotal report on the evidence of deleterious effects of secondhand smoke. The conclusions of this report were so damning that when it was released in January 2003, Minister for Health and Children Micheál Martin announced that he would ensure that all enclosed workplaces, including bars, would be smoke-free by January 1, 2004.

There was unanimous support from all political parties, but almost immediately, a campaign was initiated to block or dilute the law. An organization called the Irish Hospitality Industry Alliance was formed to lead the opposition, which included representatives of the bar owners' organizations. The main thrust of the arguments against the law were the denial of individual rights; the potential harm to Ireland's tourist industry (one of the country's biggest employers); the effect of such a law on the traditional social life in Ireland, of which cigarette smoking was, these groups claimed, an integral part; and finally, the unenforceability of such a law. These arguments were refuted not only by the Department of Health and Children and the Office of Tobacco Control, but also by a variety of nongovernmental organizations, such as Action on Smoking and Health (ASH) Ireland, the Alpha One Foun- 
dation, the Irish Cancer Society, the Irish Heart Foundation, the employers' organizations, and the trade unions. These organizations put forward the case for the new law in a variety of forums, including television and the print media and public debate. The minister for health and children visited New York and was gratified to learn that many of the problems that were anticipated by opponents of the ban had not occurred in New York after the implementation of its smoking ban.

When it was obvious that the law would indeed be implemented, attempts were made to introduce exceptions. Some exemptions were eventually included, for areas that might legally be considered a person's "home," such as hotel rooms, prison cells, and nursing homes. The debate over exemptions resulted in two changes in the date of implementation - a cause of much anxiety at the time. The threat of legal action by the hospitality industry also caused some concern. However, the minister, the government, and all the political parties held firm, and with the help of the employers' organizations, the trade unions, and the nongovernmental organizations, and especially the support of the Irish public, the law banning smoking in the workplace, the first of its kind in Europe, was implemented.
One of the great fears of the ancient Celts was that the sky would fall and crush them. After March 29,2004 , the sky did not fall in, and the Irish people did not become any more or less sociable, nor was revolution being planned in this country that has seen its share of revolution. The law banning tobacco use in the workplace was supported by the majority of the population, smokers and nonsmokers alike. The smokers who now had to go outside to smoke did so without acrimony, and the Garda Siochána (Irish police force) reported no upsurge in assaults in bars due to requests that people not smoke. Bear in mind, however, that we are talking about April, when the weather in Ireland is reasonably mild. Will the attitudes of smokers change when they are forced outside their favorite bar to smoke in the rain of an Irish winter? Perhaps, but they may reconsider the wisdom of smoking when they discover the difficulty of lighting up a cigarette in a lashing downpour while their friends are inside beside a roaring fire, drinking their low-calorie, nonalcoholic drinks. That last part may seem improbable, but wait: the minister is now turning his attention to the problems of binge drinking and obesity in the Irish population. Is no vice safe?

From the Department of Medicine, Royal College of Surgeons in Ireland, Beaumont Hospital, Dublin.

\section{Torment}

Danielle Ofri, M.D., Ph.D.

I groan when I catch sight of her name on the patient roster. Nazma Uddin. Not again! She is in my clinic office almost every month. I dread her visits, and today is no exception. A small, plump woman, Mrs. Uddin is cloaked in robe, head scarf, and veil, all opaque blue polyester. Only her eyes peer out from the sea of dark blue. She is trailed, as usual, by her 11-year-old daughter Azina, who wears a lightgreen gown with a flowered head scarf pinned under her chin but no veil covering her solemn, bespectacled face.

Mrs. Uddin flops into the chair next to my desk, with a postural sprawl that is almost teenagerly. Azina perches on the exam table, her white Nikes peeking out from under the full-length gown. Mrs.
Uddin unsnaps her veil — something she does only with her female doctor - revealing her weathered cheeks, and the litany begins. "Oh, doctor," she says, pinching the sides of her head with skin-paling force, "the pain is no good." After this brief foray into English, she slides into Bengali, aiming her barrage of complaints at Azina, who translates them to me in spurts while fiddling with her wirerim glasses. There is abdominal pain and headache, diarrhea and insomnia, back pain and aching feet, a rash and gas pains, itchy ears and a cough, no appetite. And more headache.

The feeling begins: a dull cringing in my stomach that gradually creeps outward, until my entire body is sapped by foreboding and dread. I feel my- 